The Teaching of Jesus on the Highest Good. 219

\title{
THE TEACHING OF JESUS ON THE HIGHEST GOOD.
}

By Prof. JAMES STALKER, D.D.,

Aberdeen, Scotland.

W

HEN Aristotle and the ancient thinkers spoke of the Highest Good, their meaning was that in this earthly life of ours there is for everyone a single supreme attainment, which, if missed, will render life a failure, but, if gained, will render it a success.

No one in the least acquainted with the teaching of Jesus can fail to recognize that the same assumption was constantly made by him and was even expressed in a great variety of forms. This, for example, is what is intended in such parables as the Pearl of Great Price and the Hidden Treasure. These imply that this world affords to everyone a supreme opportunity of making life worth living. But the most obvious expression of this intention is the constant use by Jesus of the word Gospel as a comprehensive name for his message. This word ev่aryé $\lambda_{\imath o \nu}$ refers, in its original sense, I suppose, to the good news brought by a swift runner to those waiting for information. It summons up in the imagination the picture of a city in a state of anxiety and uncertainty; the watchmen on the walls are looking eagerly in a certain direction; at last the messenger is descried in the distance, his manner of running betokening that he is the bearer of glad tidings. At the gate of the city he is met by the multitude, who crowd around him. He unfolds his news, which passes quickly from mouth to mouth and from group to group, till the whole city is rocking with excitement and jubilation. St. Matthew enters, exactly into the spirit of such a scene 
when he describes the commencement of the preaching of Jesus in these words: "The people which sat in darkness saw a great light, and to them which sat in the region and shadow of death light is sprung up;" and the descriptions in all the gospels of the opening ministry of our Lord, when the inhabitants of the city and village came streaming in thousands from one end of the country to the other, entirely corresponds to such a situation. In the later stages of the earthly course of Jesus this sunny aspect of his message may not have been so conspicuous; but it reasserts itself in the early preaching of the apostles after the resurrection. Wherever St. Paul, for example, went as a missionary, he must have conveyed the impression that he was bringing tidings which it concerned everyone to hear for his own welfare and happiness, and, in spite of the persecution he had to endure, he himself was borne up with the sense that he was the bearer of a secret of infinite value. This is the fundamental note of Christianity at all times; the salt has lost its savor if the preaching of the Christian pulpit does not spell Glad Tidings.

When, however, we take the next step and enquire about the contents of the good news of which Jesus was the herald, the reply is not exactly what might be anticipated. If the ordinary man were asked what the gospel of Jesus was about, he would reply without hesitation that it was the gospel "of salvation," or "of the grace of Grod," or perhaps "of justification by faith." But if requested to verify his suggestion by reference to the actual words of Christ, he would be nonplussed; because he would find no such phraseology in the record. What he would find in place of it would be "the gospel of the Kingdom," or "of the kingdom of God," or "of the kingdom of heaven," all these forms of the same phrase occurring in the gospels. Even those who are thoroughly familiar with the words of Christ have no idea how frequently these phras- 
es are found there or how completely they occupy the place of the phrases just suggested. In the beginning of St. Mark the opening of the ministry is thus described: "Now, after that John was put in prison, Jesus came into Galilee, preaching the gospel of the kingdom of God." St. Matthew describes what Jesus was doing a little later in these words: "He went about all Galilee, teaching in their synagogues and preaching the gospel of the kingdom;" and St. Luke states in like manner, "It came to pass afterwards that He went through every city and village, preaching and showing the glad tidings of the kingdom of God." When the Twelve are sent forth to do in a humbler way the same thing as was done by himself, it is reported as follows: "He sent them to preach the kingdom of God." And everyone can recall how frequently his parables begin with the formula "The kingdom of heaven is like," while the parables as a whole are designated by their author as "The mysteries of the kingdom of heaven." It would be easy to extend such quotations, were it necessary; but it may be taken for granted that Christ's own name for the supreme good of human life was the kingdom of God.

This result is a surprising one for three reasons-first, because this phrase, in which he wrapped up the kernel of his preaching, was not of his own invention. It was employed before him by John the Baptist, one of the notes of whose message was, "The kingdom of heaven is at hand." Even he, however, was not the originator. Those who dig in the literary remains of the period between the Old Testament and the New find it there; so that it was part of the religious language of the day, which Jesus, as a child of his time and country, inherited. This encourages us to enquire if it can be traced further backto the Old Testament-and, when we search we have not far to look; because in the book of Daniel we read that the great world-kingdoms, which Daniel saw in vision, were 
to be superseded by what he expressly called "the kingdom of God;" and in his famous prophecy of the Son of man, it is written,"There shall be given unto him dominion, glory and a kingdom; and all peoples, nations and languages shall serve him; his dominion is an everlasting dominion which shall not pass away, and his kingdom that which shall not be destroyed." Indeed, when thus we embark on the Old Testament Scriptures, a vast field of inquiry opens out before us. We soon realize that the entire history of the people of God in that dispensation was founded on the conception of a kingdom of God. This was the ideal which had been given to the Hebrews by Moses, and their whole actual history had been a compromise between this vision and reality. When they first demanded a king, that they might be like the other nations, they were told that God was their king and that they ought to desire no other. In the centuries that followed the history of the monarchy in Israel was far from affording clear proof that the compromise had been effectual. And deep down in the heart of the more spiritual elements of the nation, the primeval idea lingered, receiving glowing expression in the writings of the prophets. At length the earthly monarchies perished, and the nation was led away into exile, but in the gloom of captivity the ancient hope shown out again. Although the earthly monarchy was lost, all was not lost. If God would take to himself his great power and reign, the glory of the future might far excel the past. The return from Babylon was a marvellous providential intervention, which proved that Jehovah had still in reserve for his people a future and a hope. The restored state, however, proved to be only a day of small things. This was not the kingdom of God of which the prophets had spoken and for which the pious had sighed. And, as the generations went on, things grew worse instead of better. The noble effort of the Maccabees was exhausted; Herod, an ahien, was 
on the throne, and the Romans, with their irresistible force, were in the background. In all patriotic hearts smouldered the fires of discontent and indignation. Yet hope was not extinct. At length John the Baptist proclaimed, not only that the kingdom of heaven was at hand, but that after himself was coming one the latchet of whose shoes he was not worthy to unloose; and the question sent by John from the prison to Jesus, "Art thou he that should come, or do we look for another?" undoubtedly embodied the state of mind of far more than himself.

A second reason for surprise at the prominence of the kingdom of God in the teaching of Christ is the fact that it was not destined to maintain this position in the teaching of Christianity. While the phrase is very frequent in the Gospels, in the reports of Christ's own words, it is infrequent in the other books of the New Testament, and in some of these it does not appear at all. This has been quoted as evidence that the doctrine of Christianity is very different from that of Christ; but it may simply mean that new and perhaps more appropriate language had unconsciously been found for ideas essentially the same. The Apostolic age was too much alive to be the slave of phraseology, even if this were the phraseology of its master. When the apostles went forth into the heathen world, it is easy to understand that they could not speak much of a kingdom, because such language would have been misunderstood and interpreted as treason against the Roman Empire. The kingdom was an essentially Jewish idea; and, when the Jewish state had ceased to exist, the phrase was dropped as a matter of course. Since then attempts have from time to time been made to revive it. The Pietists, for example, of Germany, in the eighteenth century, loved to speak of work for the kingdom of God, instead of for the Church or for Christianity; and, strange to say, the bitterest opponents of Pietism, Ritschl and his followers, in the nineteenth cen- 
tury, have endeavored to re-introduce it as the highest category of theology. I have not observed whether in America this has commanded much assent; but there are not awanting in Great Britain scholars who have signified their agreement with it. I question, however, whether the kingdom of God is likely again to come into general use as the name for Christianity. To the common ear it has a forced and foreign sound. Kings and kingdoms do not appeal to the modern as they did to the ancient mind, some of the most advanced modern nations being republican. Still, as having been the favorite term used by our Lord for his own cause, it will always have a certain attraction for the Christian mind; and its use in two familiar words of our Lord will always prevent it from becoming antiquated-the petition in the Lord's prayer which makes us say "Thy kingdom come," and the sacred word about the little children, "Of such is the kingdom of heaven."

But the reason which most of all makes it surprising that Jesus employed this term for the highest good is that it brought Him into conflict with the ideas and expectations of his contemporaries and fellow-countrymen. It might seem to be in accommodation with these that he made use of the phrase; but it turned out that under this name they and he were thinking of entirely different things. The difference between them may perhaps be best expressed by saying that they and he laid the emphasis on different members of the phrase, they placing it on "the kingdom," he on "of God." It was of the kingdom they were thinking, that is of emancipation from the Romans, of a place and a court of their own, of influence and predominance, among the nations. He, on the contrary, was thinking of a kingdom of God-that is, of God being more fully revealed, of the will of God being done on earth as it is done in heaven. None can read the Gospels attentively without sometimes pitying the Jews 
because he was so different from the Messiah they were expecting; and the doubt may even insinuate itself into a sympathetic mind whether he was justified in employing language about a kingdom of God which they, being what they were, could hardly help misunderstanding. The tragic difference of view was not reconciled. The nation was groaning under the chastisement of the Almighty, yet it did not repent; instead of responding to the spiritual appeals of Jesus, it remained earthly and ambitious. He was only a reproach to it. To practical and worldly minds he appeared visionary; and a great resentmentand hatred invaded their hearts at the thought that such an one could presume to call himself their Messiah; this seemed to them to be casting ridicule on a great idea. This dreamer would never be able to bring to them the prizes for which they sighed, and it angered them that he should pretend to do so. Thus it was that the catastrophe was brought about, when the nation nailed him to a tree.

The stronger, however, the reasons against the use of "the kingdom of God," as the usual name for the highest that Christ had brought to the world, the more certain is it that he must have had the best of reasons for making use of it.

First, it connected his teaching with the tradition of the Old Testament and the past history of the people of God. Original and unique as Jesus is, he is never disconnected from the nation to which he belonged. His mind is saturated with the ideas of the Old Testament; his language is learned from its phraseology; the figures of the patriarchs and the pious kings occupy his imagination; and he knows himself to be the successor and the heir of the prophets. If the kingdom of God was the underlying idea of the whole Old Testament history, this was the best reason for its being the most prominent watchword of his preaching.

Secondly, he was influenced in adopting this phrase by 
the home in which he was brought up. In the Jewish society of his time there was one section in which the tradition of the past was cherished in peculiar purity; its members are sometimes designated by the name of the $\Pi \rho o \sigma \delta \epsilon \chi \alpha^{\prime} \mu \epsilon \nu o$, which simply means that they were waiting for the kingdom of God. To this section belonged the home in which Jesus was born and brought up, as did that of John the Baptist; and in the songs which emanated from this circle in the era of the Advent, and which have been preserved in the commencement of the Gospels, we possess the most vivid image of the hopes with which their minds were filled. These all center in the kingdom of God. These pious souls were pining and praying day and night over the degradation of their country and watching for the dawn of a better day, to which they applied this name. In making use of this term Jesus is sometimes spoken of as accommodating himself to the ideas of his time; but, in truth, he was employing language as native to himself as were the syllables he prattled at his mother's knee

But, thirdly, the reason for the use of this name must be sought still deeper in his own consciousness. He knew himself to be the Messiah of his people, under whose kingship the highest good of man was to be enjoyed. It is true he kept back his acknowledgement for a time, at least in certain circles, mainly because of the contrast already spoken of between that which he intended by the name Messiah and that which his contemporaries understood. But, when his disciples at Cæsarea Philippi acknowledged him to be the Christ, he made it perfectly manifest that he accepted the title; and, before the end came he testified to the entire nation by his triumphal entry into Jerusalem what the claim was which he made. It is difficult to avoid sometimes asking what would have happened if this claim had been conceded and the Jewish nation had heartily accepted him as its Messiah. Would 
he have ascended the throne of the country and thence ruled the world? To such a question there is of course no answer. But surely we may say that the world missed an incomparable splendor when, instead of hailing Jesus of Nazareth as king of the Jews, the inhabitants of Jerusalem cried out "Crucify him." That, however, which from one point of view was the hostile will of his blind fellow-countrymen was from another the will of Heaven; and Jesus accepted it as such. We cannot think of it but as a cruel disappointment to him when the current of events bore him away from the goal to which he was striving; but, just because it was at the same time the current of Providence, he not only obeyed it but found in it a divine guidance to a prize still more desirable than the one he had missed. And so Jesus remains forever the supreme illustration of that faith in Providence which he recommended to others. He was led, like one blind, by a way that he knew not; and he won all by losing all. As early as the temptation in the wilderness he had had to face the alternative of a vast external kingdom without interior reality and a small kingdom with genuine power; and he had-not indeed without a struggle, but decisively and irrevocably - chosen the latter. The Jewish people adhered to their own conception of the kingdom of God, working it out till it issued in his crucifixion; but no less resolutely did Jesus adhere to his own conception of the same, working it out in the choice and training of his followers. Of these there were only twelve; and at his death the circle had only extended to five hundred; but these were the nucleus of a kingdom destined to become worldwide; and in them his own conception of what the kingdom of God should be was actually fulfilled.

It is now, however, high time to be asking what are the permanent elements in the teaching of Jesus about the kingdom of God and what message for ourselves it still contains; for, even if we do not adopt the language of 
Jesus, certainly the ideas and the spirit which he poured into this phrase are still of importance for us.

First, there are those who would say the chief lesson to be derived by us from this phrase is what it teaches about the social nature of Christianity-a kingdom being not of one but of many, linked together in gradations of honor and mutual helpfulness. Jesus, they say, delivered mankind from an individual and selfish view of religion and introduced a religion of brotherhood and common endeavor. The conception of religion, however, as a corporate impulse, so far from being a discovery of Jesus, was common to the whole ancient world. This is especially the view of the Old Testament, in which both the reproofs and the promises of the Prophets are addressed not to individuals, but to the nation at large, and only slowly and dimly, as the book is drawing to a close, does the truth emerge, that the individual is capable of a personal relation to God. It would be truer to affirm that Jesus stripped religion of its national character and made it individual. Yet to say so would only be to state half the truth. The individuality which he teaches is at the same time universality; because a society into which every individual can enter, without regard to age, station or race is really universal, the only qualification consisting in that which is common to all men. Herein, then, consists the originality of Jesus; He stripped religion of its national and racial character making it individual, in order that thereby it might become universal. The religion of Jesus Christ is, in the first place, a personal experience, a secret blessedness, a spiritual discovery, filling the soul with a joy which makes every sacrifice appear light on which its possession depends; and then in the second place, it is a glorious brotherhood and league of endeavor and victory.

Another idea which is kept fresh by this phrase is that of Loyalty. Kings and kingdoms may not now, as has 
been already acknowledged, bulk as largely as they once did in the thoughts of men; but loyalty is an indispensable sentiment, the inspiration of all high endeavor. In the steamer in which I recently crossed the ocean to America, I was conversing with a fellow-passenger about a man of great eminence recently deceased in the Methodist church, of which my interlocutor is himself an ornament, and after discussing the qualities of the departed servant of God, he added, "But that which really accounted for his life was an enthusiastic love for the Son of God." This is what I mean by loyalty; and without loyalty to the king there will never be much done, for the kingdom of God.

A third idea kept fresh by this phrase is man's immortal destiny. When the kingdom of God is named in the hearing of the common man, what he thinks of is a place in some distant part of the universe, which will be the portion of true Christians after death. It need hardly be said that this was not what Jesus meant by the phrase; yet this is included in his conception, as may be supposed to be especially indicated when he employs the form, the "kingdom of heaven" instead of the "kingdom of God." It is in the Gospel of St. Matthew that the former occurs, this evangelist frequently making Jesus say the "Kingdom of heaven" where the others report him as saying the "kingdom of God." There has, indeed, been much learned discussion as to the reason of this substitution. Some suppose that "heaven" is simply a name for God; so we use it ourselves in such a phrase as "Heaven help him;" and Jesus himself employs the word in this sense when he makes the prodigal son say to his father, "I have sinned against heaven and before thee." Others suppose it to indicate the source from which the kingdom is derived or to which it is akin. But the best explanation is that it expresses Christ's own abiding consciousness of the existence of a portion of the 
universe in which all that he desired for this world is at all times perfectly fulfilled. Heaven is not a future state, as it is often called, but a present state; the ideal is already actually realized; and the desire of Jesus was only to extend its reign. Of course, however, heaven is likewise a future inheritance, which will compensate for all the sacrifices entailed on the disciples of Jesus in this world and repair all the imperfections of which they were conscious. Even to the writers of the Old Testament, the belief in it was dim and occasional; but Jesus dwelt in his region as in his home and fatherland, and certainly this formed a large part of all his promises.

But by far the most important idea embodied in the "kingdom of God" is that indicated by Jesus himself, when, in the Lord's Prayer, he expounds the petition, "Thy kingdom come" by the one which follows, "Thy will be done on earth as it is in heaven." Wherever in a nation or a home or a heart, the will of God is done, there the kingdom of God exists; and this is something which never grows old. For the will of God Jesus had the most passionate love, into which entered all the feeling he had for his Father in heaven, as well as all the hope he cherished for the improvement of the world. When any human being did the will of God, Jesus said, "The same is my brother and sister and mother." At the crisis of his passion in Gethsemane, the discords of his soul were resolved in the prayer, "Not my will, but thine be done." Where God's will is done, there may, for the moment, be suffering and renunciation, as there were in his own case, but ultimately there must be success and happiness; for the stars in their courses fight on behalf of the man who is doing the will of God, and all the winds of heaven waft him to his goal.

This is the thought expressed in the Beatitudes, with which the Sermon on the Mount opens and in which the true key-note of all his testimony is sounded. Eight times 
over is the word "Blessed' rung out, as if to make audible the whole gamut of its music. The structure of these remarkable utterances of the Lord is often misunderstood, it being supposed that the justification of the predicate, "blessed," lies in the subject of each sentence, in which the character of true discipleship is defined; it really lies in a small supplementary sentence introduced in each beatitude by the conjunction "for" - "for they shall be comforted;" "for they shall see God;" "for they shall be called the children of God;" and so on. Or rather each beatitude is an equation, on the one side of which stands "blessed," while on the opposite side there are two magnitudes, the one expressing the spiritual condition of those spoken of and the other a new condition into which they are about to pass, the one of these may be a negative quantity, as when it is said, "Blessed are they that mourn," but the other is so large a positive quantity that the two together exhibit a magnificent "plus" of happiness. It is very significant that both the first and the eighth of these explanatory clauses, in which the kernel of the Beatitudes lies, are identical, and that in both the kingdom of heaven is named as the essence of blessedness-"Blessed are the poor in spirit for theirs is the kingdom of heaven," "Blessed are they that are persecuted for righteousness' sake, for theirs is the kingdom of heaven." This indicates again, with extraordinary clearness, what $I$ have been saying all through this article, that the kingdom of heaven is Christ's own expression for the Highest Good. In the Beatitudes, after the first, it may be presumed,the teacher is exhibiting in detail the various kinds of blessedness, wrapped up in the kingdom of God; but, having reached the seventh, he has nothing more to add, but simply repeats the first, thus sounding forth as the octave the note which has already served as the keynote. 
"What," asks Aristotle, "is the highest of all realizable goods? As to its name, I suppose nearly all men are agreed; for the masses of men and the men of culture alike declare that it is happiness." Against this dictum the stoics, in ancient times, declaimed, ridiculing the desire for happiness felt by every human heart; and in our own time Thomas Carlyle has taken up their parable, scoffing at the notion, taken for granted, as he would say, in every foolish brain, that anyone needs to be happy or has any natural right to happiness. Men are miserable, he argues, because they entertain exorbitant notions of their own deserts and are astonished when nature does not agree with them; but let them take it for granted that they deserve nothing, and then the slightest favors of fortune will be welcomed as surprises. But the desire for happiness is far too deeply seated in the human soul to be argued away by any eloquence. Jesus, ever true to nature, acknowledged it as one of the primordial forces of our being, and endeavored to enlist it among the motives of goodness. Only he put the word "blessedness" in the place of the word happiness - a simple yet a radical change ; because blessedness is a happiness pure and spiritual, reaching down to the profoundest elements of human nature and reaching forth to the illimitable developments of eternity. 